\author{
Wiola Próchniak \\ Katolicki Uniwersytet Lubelski \\ e-mail: violape@kul.pl \\ ORCID: 0000-0002-3424-6135
}

\title{
REWOLUCJA FUNKCJONALNA. O LITERACKICH I KULTUROWYCH ASPEKTACH NAUCZANIA JĘZYKA POLSKIEGO JAKO OBCEGO
}

Rzeczywista znajomość języka - określana mianem biegłości językowej - oznacza nieograniczony dostęp do tekstów kultury poznawanego języka, przy czym najbardziej oczywistym działaniem językowym wydaje się czytanie tekstów literackich.

Większość współcześnie praktykowanych metod glottodydaktycznych ogranicza jednak dobór prezentowanych tekstów do tych podstawowych, organizujących czy wspierających nasze życie codzienne - należą do nich formularze, ulotki reklamowe, menu, ogłoszenia, a także krótkie teksty prasowo-blogowe przywołujące po części obiegowe opinie, po części zaś wyselekcjonowane fakty. ${ }^{1}$ Można to dostrzec, przeglądajac podręczniki do języka polskiego jako obcego $z$ ostatnich dwóch dekad - atrakcyjne dla oka, sprawnie prezentujące słownictwo i struktury - w przeważającej mierze obywają się one bez tekstów o charakterze artystycznym. Dzięki tym materiałom $z$ powodzeniem kształcone sa - i nabywane - sprawności językowe.

\section{KOMPETENCJE}

Sama zdolność wymiany komunikatów nie wyczerpuje jednak potrzeb językowych użytkowników języka. Często w trakcie rozmowy okazuje się, że kompetencja kulturowa czy - idąc krok dalej - międzykulturowa [zob. Byram 1997; Myczko 2005; Bolten 2006, 2010; Nikitorowicz 2013; Mihułka 2014; Majkiewicz 2016] sa koniecznymi narzędziami nie tylko skutecznego komunikowania się, ale przede wszystkim autentycznego porozumienia. Jak wynika $z$ definicji słownikowych, kompetencja to „zakres czyjejś wiedzy, umiejętności i odpowiedzialności"; ${ }^{2}$ natomiast

1 Podobne spostrzeżenia formułowała przed laty Marzena Żylińska [2003].

2 Słownik języka polskiego, Warszawa 1997, hasło: kompetencja (przedruk elektroniczny, przygotowany przez Redakcję Słowników Języka Polskiego PWN i firmę Litterae). 
Słownik języka polskiego umieszcza w definicji tego terminu również „doświadczenie”. Warto zaznaczyć, że francuskie słowo compétence oznaczało dawniej zdolność wykonania zadania i odnosiło się do kształcenia zawodowego. Natomiast dokument przygotowany przez Radę Europy ujmuje to tak:

Pod pojęciem kompetencji rozumiemy całość wiedzy deklaratywnej, sprawności i umiejętności oraz cechy charakteru danej osoby, które to czynniki determinuja jej sposób działania [ESOKJ 2003, 20].

To objaśnienie odsłania dodatkowy, a jednocześnie istotny poziom znaczeniowy, a mianowicie charakter człowieka i jego indywidualność, co wydaje się $z$ perspektywy prowadzonych rozważań szczególnie warte podkreślenia.

\section{METODY}

Wśród metod stosowanych obecnie w glottodydaktyce polszczyzny można wskazać trzy dominujące. Należą do nich podejście komunikacyjne, metoda między/kulturowa ${ }^{3}$ oraz podejście zadaniowe. Najpopularniejsze wśród nich podejście komunikacyjne - ukształtowane w latach 70. XX w., obecne w nauczaniu języka polskiego jako obcego od lat 90. - ma szerokie grono zwolenników zarówno wśród nauczycieli, jak i uczniów ze względu na swój praktyczny i efektywny wymiar. Podejście zadaniowe natomiast zdefiniowane przed kilkunastu laty przez europejskich ekspertów [ESOKJ, 20-26], a następnie opisane $z$ perspektywy nauczania języka polskiego jako obcego przez Iwonę Janowską [Janowska 2011], choć korzysta $z$ dorobku komunikacyjności, wskutek przesunięcia akcentów udostępnia glottodydaktykom nowe narzędzia. Warto zwrócić uwagę na elementy, które odróżniaja te dwa podejścia. Podczas gdy w metodzie komunikacyjnej koncentrujemy się na użyciu języka ( $z$ akcentem na sprawności językowe: słuchanie, mówienie, czytanie, pisanie), w podejściu zadaniowym na pierwszy plan wysuwaja się działania językowe (recepcja, produkcja, interakcja i mediacja). Dla „komunikacjonistów" podstawowa jednostka nauczania jest ćwiczenie, dla „działaniowców” - zadanie. ${ }^{4}$ Fundamentalna odmienność polega więc na

3 Międzykulturowy model nauczania zakłada otwartość (nauczanie zadaniowe i otwarte), aktywność (zaangażowanie i kreatywność uczestników), autopoznanie (przekaz wiedzy, formułowanie poglądów), dynamiczność (procesualność przekazu kulturowego), konstruktywność i dialogowość (wiedza nabywana poprzez dialog), różnorodność (odniesienie do różnych systemów znaczeń), autentyczność (negocjowanie znaczeń) [Torenc 2007, 141-143].

4 „Działania językowe, za pomocą których są realizowane zadania komunikacyjne, polegaja na przetwarzaniu (rozumieniu lub tworzeniu w wyniku interakcji lub mediacji) tekstów w formie pisanej lub mówionej" [ESOKJ 2003, 25]. 
tym, że automatyzm rozwiąywania ćwiczeń zmienia się w możliwość rozwiązywania problemów, co przybiera formę złożonego, wieloetapowego procesu wiażącego się $z$ koniecznością wykonywania złożonych operacji kognitywnych.

Porównując natomiast podejście zadaniowe $z$ metodą kulturowa, odwołam się do zestawienia opracowanego przez Jerzego Kowalewskiego [Kowalewski 2013, 266]:

\begin{tabular}{|l|l|}
\hline \multicolumn{1}{|c|}{ Podejście zadaniowe } & \multicolumn{1}{c|}{ Podejście kulturowe } \\
\hline $\begin{array}{l}\text { Język - komunikacja: działanie } \\
\text { społeczne. }\end{array}$ & $\begin{array}{l}\text { Kultura - kontakt: bycie razem w przestrzeni } \\
\text { kulturowej. }\end{array}$ \\
\hline $\begin{array}{l}\text { Działania językowe: rozumienie } \\
\text { tekstów (recepcja), tworzenie tek- } \\
\text { stów (produkcja), przetwarzanie } \\
\text { istniejacych tekstów (mediacja), } \\
\text { wymiana informacji (interakcja). }\end{array}$ & $\begin{array}{l}\text { Działania kulturowe: rozumienie kultury, jej } \\
\text { przyjmowanie (interioryzacja) i przetwarzanie, } \\
\text { wymienianie się informacjami kulturowymi } \\
\text { (eksterioryzacja), wytwarzanie dóbr kultury } \\
\text { wedle wzorców, uczestnictwo w kulturze. }\end{array}$ \\
\hline Zadanie. & Zadanie kulturowe. \\
\hline Nauczyciel jako partner/doradca. & $\begin{array}{l}\text { Nauczyciel jako autorytet, przewodnik po } \\
\text { swiecie kultury, inspirator do uczestnictwa } \\
\text { w kulturze. }\end{array}$ \\
\hline
\end{tabular}

Na podstawie: Kowalewski 2013, 266.

Dostrzec tu można istotne różnice w zakresie narzędzi i przestrzeni komunikacji, w sferze działań nadawczo-odbiorczych, w charakterze podejmowanych zadań, a także w funkcji nauczyciela, choć odnoszę wrażenie, że rola "nauczyciela jako autorytetu” to zaledwie znikoma część jego powinności. Inspirowanie do wchodzenia w przestrzeń kultury, prowadzenie uczniów / studentów przez kulturowe meandry, a jeszcze bardziej wspólne przeżywanie zjawisk kulturowych i dążenie do odczytywania tekstów kultury, przybiera formę wspólnego działania - współdziałania i to właśnie uznać należy za doświadczenie najcenniejsze. W tym procesie bowiem dokonuje się nie tylko doskonalenie „zewnętrznych”, instrumentalnych kompetencji językowych, ale także następuje rozwój tej sfery człowieka, która rozciąga się pomiędzy wrażliwościa i ciekawością a doświadczeniem i wiedzą. Nie bez znaczenia jest również fakt, że w tej przestrzeni niezależnie od wieku i pełnionej roli wszyscy jesteśmy uczniami. I ten swego rodzaju demokratyzm, angażujac nas emocjonalnie i intelektualnie, ma szczególną wartość wspierająca proces nauczania.

Zdaniem Waldemara Pfeiffera: ,interkulturowa kompetencja komunikacyjna (...) zakłada znajomość podstawowych elementów kultury obcej rzeczywistości i umiejętność płynnego i adekwatnego użycia języka" [Pfeiffer 2001, 149]. O ile więc kompetencja kulturowa świadczy o znajomości określonej kultury, o tyle za jej dopełnienie należy uznać wrażliwość interkulturowa, która tworzą: „Wiedza, świadomość i rozumienie relacji 
(podobieństw i wyraźnych różnic) między światem społeczności pochodzenia a światem społeczności języka docelowego (...)" [ESOKJ 2003, 96]. Zdolność ta pociaga za sobą kompetencję interkulturowa i umiejętności interkulturowe. Wiąże się to również ze sferą emocjonalną i pozytywnym nastawieniem wobec nowych treści, budzeniem ciekawości, potrzebą wypowiadania własnych opinii, podejmowaniem dyskusji, bowiem -

Na kompetencję interkulturową składa się - oprócz tradycyjnych sprawności językowych i komunikacyjnych - wiele elementów odwołujacych się do zrozumienia i interpretacji tego, co obce: wrażliwość, empatia, umiejętność respektowania innych poglądów, zdolność akceptowania niejednoznacznych sytuacji, umiejętność patrzenia na świat $z$ różnych perspektyw itp. [Kaikkonen 1997; za: Żylińska 2003, 52].

Tak więc w ujęciu interkulturowym koncentrujemy się na kompetencjach węzłowych, do których można zaliczyć: umiejętność słuchania, empatię, rozumienie postaw i zachowań reprezentantów różnych kultur, tolerancję i otwartość na odmienność, umiejętność unikania i/lub rozwiazywania konfliktów, a także radzenie sobie w sytuacjach niepewnych [por. Korczyński 2017, 152-154]. Przywołane powyżej formy reagowania nie moga umknąc uwadze nauczyciela. Powinny one stać się ogniwem nie tylko pojedynczej lekcji, lecz także całego procesu dydaktycznego. Rozwijanie kompetencji interkulturowej [Zarzycka 2000; Pfeiffer 2001, 148-149; Żydek-Bednarczuk 2015, 67-79] opiera się na trzech komponentach - sa to interakcja oraz znajomość kultury własnej i obcej - które $\mathrm{w}$ istocie maja prowadzić do negocjowania znaczenia komunikatów i właściwego rozumienia się, to znaczy: do „porozumienia się" stron dialogu [Zarzycka 2000, 32-33; Jaskuła, Korporowicz 2017, 33-43]. To, co należy poznać - uświadomić sobie, przemyśleć, przedyskutować - odnosi się do wielu aspektów kultury i języka, które za Alexandrem Thomasem można opisać następująco:

Standardy kulturowe to wszystkie rodzaje postrzegania, myślenia, wartościowania i postępowania, które sa uznawane przez większość członków danej kultury jako normalne, oczywiste, typowe i obowiazujace. Zachowanie własne i obce jest oceniane i regulowane właśnie na podstawie standardów kultury [Thomas 2003, 112].

Nie tylko wiedza obejmująca fakty i artefakty, lecz także sposób myślenia, bycia i życia - kultura jako czasownik [Nycz 2017, 61] - pozwala lepiej zarówno rozumieć siebie, jak i określić siebie w odniesieniu do kultury, z której się wywodzimy, a także w relacjach nawiązanych lub nawiązujących się $z$ innymi.

\section{POSTAWY - MOTYWACJE - TOŻSAMOŚĆ}

Tak więc samopoznanie i samoświadomość wpływaja na naszą gotowość - lub jej brak - do wchodzenia w interakcje bliższe (wewnątrzkulturowe) i dalsze (międzykulturowe). Bez wątpienia - 
Stosunki międzykulturowe można rozpatrywać na poziomie postaw, motywacji i tożsamości jednostek. Tożsamość kulturowa jest natomiast wytworem zbiorowej tradycji i sieci powiazań interpersonalnych (...) istnieje cała sfera czynników determinujących sposoby przeżywania i interpretowania „swojskości” i „obcości”, podobieństw i różnic kulturowych. Należą do nich takie czynniki, jak cechy terytorium i rodzaj więzi historycznych $z$ nim zwiazanych, usytuowanie grupy w przestrzeni i warunki środowiska naturalnego, skład populacji i jej atrybuty demograficzne, rodzaj stosunków wła$\mathrm{dzy}$, stan rozwoju infrastruktury, sposoby gospodarowania i wiele innych [Paleczny 2017, 29].

Przestrzeń kulturowa - ze względu na swoją rozległość i złożoność nie poddaje się łatwo opisowi. Można próbować ją uchwycić w różnych jej przejawach, trudno natomiast stworzyć pełny, kompletny jej obraz. Glottodydaktycy podejmuja takie próby, pisząc podręczniki, ${ }^{5}$ tworząc materiały dydaktyczne i źródłowe, ${ }^{6}$ sięgając po wyraziste teksty kultury ${ }^{7}$ czy po prostu prowadząc zajęcia językowe, które ostatecznie przyjmuja formę negocjacji - pomiędzy tym, $z$ czym przychodzimy na zajęcia, a tym, $z$ czym $z$ nich wychodzimy (w trakcie nauki języka następuje nie tylko prezentacja wybranych zjawisk językowych i kulturowych, ale także wynikająca $z$ dialogowej natury spotkania wymiana myśli, opinii, wiedzy, doświadczeń, wartości).

Narzędzia do diagnozowania indywidualnego etapu w rozwoju interkulturowym opisał Milton Bennett, tworząc model rozwojowy wrażliwości międzykulturowej [Bennett 1993, 21-71], ${ }^{8}$ w którym wskazuje na istnienie trzech faz etnocentryzmu. Definiuje je jako:

1) zaprzeczenie istnienia różnicy kulturowej - na tym poziomie kultura własna uznawana jest za jedyna prawdziwa, a typowe zachowania to unikanie inności poprzez izolację psychiczną i fizyczną (reprezentanci tej fazy nie wykazuja zainteresowania różnicami kulturowymi);

2) obrona przed różnicą kulturową - pojawia się świadomość różnic kulturowych, lecz tylko kultura, z która osoba się identyfikuje, uznawana jest za jedyna właściwa; postrzeganie świata ma charakter dualistyczny, co prowadzi do dzielenia ludzi na lepszych („swoich”)

$5 \mathrm{~W}$ innych pracach pisałam na temat obecności i funkcji literatury w podręcznikach do nauki języka [Próchniak 2012; 2018, 13-16; 2020, 51-53].

6 Warto tu odnotować projekt Leksykonu kultury polskiej dla cudzoziemców, w którym zaplanowano takie kategorie jak: informacje ogólne o Polsce; historia i polityka; miejsca; obyczaje, realia, zagadnienia socjokulturowe; mitologia i folklor; historia kultury polskiej; nauka i oświata [zob. Zarzycka 2008, 183-189].

7 Wśród wielu interesujących publikacji wykładowców Szkoły Języka i Kultury Polskiej UŚ znajduje się książka Na wyrywki. 100 cytatów z polskiej poezji $i$ dramatu, które powinien znać także cudzoziemiec [2018]. Jest to zbiór fraz i wyrażeń, które utrwalone w polskiej świadomości pełnia funkcję skrótów myślowych, lapidarnych podsumowań czy zastępników tytułów, są ważną częścią aluzyjnego języka o proweniencji literackiej i kulturowej.

8 Por. także Nikitorowicz i in. 2013, 34-35. 
i gorszych („obcych”), natomiast podstawowa reakcją wobec innych kultur jest krytycyzm;

3) minimalizacja różnicy kulturowej - w tej fazie następuje koncentracja na podobieństwach kulturowych przy równoczesnym ignorowaniu odmienności.

Dopełnieniem tego procesu sa trzy fazy etnorelatywizmu:

1) akceptacja różnicy kulturowej, gdy pojawia się przekonanie, iż kultura własna jest jedna $z$ wielu, a różnice zostaja zauważone i uznane, jednak w tej fazie obserwuje się brak zainteresowania i szacunku wobec innych kultur;

2) adaptacja - faza rozszerzenia własnego światopoglądu, czego przejawem sa nowe formy zachowań i umiejętności (m.in. empatia), które ułatwiają komunikowanie się $z$ reprezentantami innych kultur;

3) integracja, czyli próba łączenia różnych perspektyw kulturowych; postawa ta przybiera formę procesu, w którym następuje ciagłe redefiniowanie własnej tożsamości.

Uważniejsze przyjrzenie się diagnozie Miltona Bennetta pozwala zrozumieć drogę, która na swój sposób przebywa każda osoba uczaca się nowego języka i wchodząca w nową kulturę. Natomiast doświadczenie pełnej integracji kulturowej określone jest mianem „trzeciego miejsca”/ "third space” [Kramsch 1993, 9], „trzeciej wartości” [Mostwin 1995, 13] lub zmiennej przestrzeni socjosemantycznej [Wierzbicka 1990, 103], które definiują egzystencję osoby żyjącej i działającej w dwóch kulturach, doświadczającej obu i $z$ obu czerpiącej wartości.

Inna perspektywę przyjmuja Guo-Ming Chen i William J. Starosta [zob. Chen, Starosta 1996; Świdzińska, Maliszewski 2019], którzy wyodrębniają i opisuja międzykulturowość w wymiarze poznawczym, afektywnym i behawioralnym. ${ }^{10} \mathrm{~W}$ ich ujęciu modele kompetencji do komunikacji międzykulturowej dotyczą świadomości, wrażliwości i sprawności:

\begin{tabular}{|l|l|}
\hline $\begin{array}{l}\text { świadomość } \\
\text { międzykulturowa }\end{array}$ & $\begin{array}{l}\text { wymiar poznawczy - zdolność człowieka do rozumienia } \\
\text { podobieństw i różnic innych kultur }\end{array}$ \\
\hline $\begin{array}{l}\text { wrażliwość } \\
\text { międzykulturowa }\end{array}$ & $\begin{array}{l}\text { wymiar afektywny - emocjonalne pragnienie danej osoby } \\
\text { zrozumienia, docenienia i zaakceptowania różnic kulturowych }\end{array}$ \\
\hline $\begin{array}{l}\text { sprawność } \\
\text { międzykulturowa }\end{array}$ & $\begin{array}{l}\text { wymiar behawioralny - zdolność jednostki do osiagania celów } \\
\text { komunikacyjnych w czasie integracji z ludźmi z innych kultur }\end{array}$ \\
\hline
\end{tabular}

Na podstawie: Chen, Starosta 1996.

9 Jak pisze autorka: „(...) emigrant wytworzy w sobie trzecia wartość, która stanie się forma pośrednią pomiędzy identyfikacją $z$ krajem pochodzenia a identyfikacja $z$ krajem osiedlenia, a jednocześnie bardziej zróżnicowaną i wyższą forma ludzkiego rozwoju" [Mostwin 1995, 13].

$10 \mathrm{~W}$ innych opracowaniach trzeci komponent jest określany mianem konatywnego (dotyczącego postaw) [zob. Gertsen 1990, 341-362]. 
Można zatem mówić o wiedzy na temat zasobów kulturowych, norm i wartości obowiąujących w innej kulturze, o budowaniu postawy otwartości na inność i elastyczności w związku $z$ odmiennościa, czyli o szeroko rozumianej tolerancji, a także o sprawności językowej wzbogaconej o uważność, świadomość wieloznaczności, chęć podejmowania dialogu i pozytywne nastawienie w kontaktach $z$ reprezentantami innej kultury i wobec odmiennych sposobów bycia / norm zachowania wynikajacych $z$ identyfikacji $z$ określoną społecznościa.

\section{W ŚWIECIE WARToścI}

Zbudowanie kompletnego systemu wartości wiąże się $z$ czynnikami zewnętrznymi, a jednocześnie wynika $z$ osobowości człowieka (jego charakteru, samoświadomości, emocji, które przeżywa oraz ze sposobu interpretowania własnych doświadczeń). Każdy $z$ nas koncentruje się na wybranych wartościach - tworzą one pewien układ, w którym jedna wynika $z$ drugiej. Przywoływana już wcześniej Danuta Mostwin podpowiada, iż z polskiej perspektywy do najważniejszych należa takie kategorie jak poszanowanie wolności indywidualnej i grupowej, szacunek dla honoru (godności) człowieka i narodu, szacunek dla mądrości i doświadczenia starszego wieku, lojalność rodzinna, narodowa i w diasporze, język polski (literatura) i jego historia, sztuka (w tym sztuka folklorystyczna) polska, zwyczaje i obrzędy, które są symbolami i nadają rytm życiu, stosunek do przyrody - harmonijne współżycie $z$ otaczającym światem, wartość przyjaźni, która przekracza znaczenie sąsiedzkiej znajomości i koleżeństwa, a także wyczucie hierarchii wartości [Mostwin 1995, 49]. Zapewne wielu ludzi byłoby skłonnych uznać ten system za własny, odnaleźć w nim przekonania, które determinują sposób życia i dokonywane wybory. Bez watpienia dotyczyłoby to również - w jakimś stopniu - osób wywodzacych się $z$ odmiennych kultur. A jednak ten kanon zasad i przekonań, w dużej mierze zdawałoby się uniwersalnych, przestaje być jednoznaczny $\mathrm{w}$ praktyce, ponieważ zdarza się, iż wartości - te same $z$ nazwy - sa w różnych kulturach aktualizowane inaczej.

I chociaż wiedzę o społeczeństwie i kulturze określonej społeczności można uznać za część wiedzy ogólnej, nie należy tego bogatego zakresu znaczeń minimalizować w procesie nauczania języka. Jest ona ważna i użyteczna dla uczącego się, także dlatego, że nie musi łączyć się z jego wcześniejszymi doświadczeniami, bywa zniekształcona stereotypami lub nieczytelna ze względu na odmienność zachowań i reguł obowiazujących w różnych społecznościach. Dlatego też m.in. w ESOKJ zestawiono przestrzenie, w których doświadczamy specyfiki kultury lokalnej. Znalazły się wśród nich życie codzienne, warunki życia, stosunki międzyludzkie, systemy wartości, poglady i postawy, język ciała, konwencje społeczne, zachowania rytualne [ESOKJ 2003, 95-96]. Powinny one stać się ele- 
mentami procesu kształcenia językowego, ponieważ przywoływanie i wyjaśnianie zjawisk $z$ tych zakresów pozwala się $z$ nimi oswoić i jeśli nawet nie zostana przyjęte za własne, stana się przynajmniej bardziej zrozumiałe.

\section{Przekazywanie treści kulturowych - metody}

Nauczanie języka skoncentrowane na treściach kulturowych ${ }^{11}$ opisuja między innymi autorzy Innego punktu widzenia [Zarzeczny, Piekot 2010, 199-206], wskazujac na następujace rozwiazania praktyczne:

1) nauczanie faktograficzne, w którym dominuje wiedza historyczna i z zakresu kultury wysokiej, natomiast informacje geograficzne, gospodarcze i polityczne występuja jako składnik dodatkowy, zwykle w formie krótkich tekstów do czytania;

2) nauczanie komunikacyjne na podstawie autentycznych tekstów (np. prasowych) dotyczacych realiów zwiazanych $z$ takimi zakresami jak rodzina, zakupy, zdrowie, praca, edukacja etc.;

3) nauczanie interkulturowe / międzykulturowe, które polega na stosowaniu odpowiednich strategii językowych, negocjowaniu znaczeń $\mathrm{i}$ interpretacji zjawisk kulturowych w odniesieniu do posiadanej wiedzy na temat poznawanego kraju i/lub doświadczeń wyniesionych $z$ własnego kręgu kulturowego;

4) nauczanie eklektyczne integrujace wymienione techniki i koncentrujace się na wiedzy przekazywanej w poznawanym języku, refleksji nad formułowanymi przekonaniami, tworzeniem własnej wizji świata. Wymienione techniki podpowiadaja, jakie rozwiazzania stosować w nauczaniu językowo-kulturowym, nie wyczerpuja jednak wszystkich możliwości. W związku z „czytaniem” tekstów kultury glottodydaktyka dysponuje zróżnicowanym zestawem narzędzi. Oto niektóre $z$ nich:

- pedagogika dyskursywna rozumiana jako ścieranie się dyskursów i negocjowanie znaczeń inspirowane tekstami literackimi [Czerkies 2012a; 2012b];

- podejście językowo-literackie polegajace na otwieraniu tekstu literackiego w sekwencji działań na poziomie leksyki, gramatyki, semantyki tekstowej i kontekstowej / kulturowej [Próchniak 2012; 2018; 2020];

- podejście interkulturowo-porównawcze ${ }^{12}$ na podstawie tekstów prasowych [Wilczyńska 2012; 2013];

11 O trzech modelach nauczania kultury i zagadnień realioznawczych - faktograficznym, komunikacyjnym oraz międzykulturowym - pisał Przemysław Gębal [2006, 207-211].

12 Zdaniem Weroniki Wilczyńskiej analizowanie artykułów prasowych prowadzi do integracji kompetencji medialnej i interkulturowej, przy czym dyskurs jest rozumiany jako ,język w użyciu” albo „tekst w kontekście” [zob. Wilczyńska 2012, 11]. 
- CLIL zintegrowane nauczanie językowo-przedmiotowe, czyli nauczanie języka przez treść $z$ mocnym akcentem na „uwrażliwianie uczniów na kwestie wielokulturowości" [Handzel 2014, 146-147] i pokonywanie bariery komunikacyjnej [Janus-Sitarz 2014]; ${ }^{13}$

- czytanie krytyczne, czyli dydaktyka pytań - w szerszym ujęciu jest to krytyczne czytanie tekstów informacyjnych w perspektywie dydaktyki językowo-kulturowej, przy czym krytyczność jest rozumiana jako postawa charakteryzująca się skłonnością do oceny (prze)czytanych tekstów [zob. Hadaś 2020, 76];14 autorka wyróżnia 4 typy lektury: dekodowanie (Co jest napisane?), czytanie ze zrozumieniem (Co tekst mówi?), czytanie krytyczne (Co tekst czyni? - Jak tekst oddziałuje?), zaawansowane czytanie krytyczne (Co tekst czyni: dlaczego i jak?) [zob. Hadaś 2020, 84].

W ostatnich latach powstało również sporo materiałów poświęconych teorii i praktyce prezentowania tekstów literackich na zajęciach $z$ nauczania języka polskiego jako obcego. Ksiażki autorstwa Tamary Czerkies Bliżej tekstów [2016] oraz Literackie lustro kultury [2019] to znakomite wprowadzenia do czytania polskiej literatury przez cudzoziemców. Ukazały się również dwie publikacje Literatura i glottodydaktyka w praktyce. Tekst literacki $w$ nauczaniu języka polskiego jako obcego [2018] oraz Literackie obrazy kultury. Perspektywa glottodydaktyczna [2020], które polska rzeczywistość - jej przejawy materialne i mentalne, uchwycone w literaturze - ukazuja w perspektywie otwartej na obcojęzycznych czytelników.

\section{Język w użyciu}

Nie traci swej aktualności myśl Hansa-Georga Gadamera, iż używanie języka obcego $\mathrm{w}$ dialogu $z$ drugim czy też przez poznawanie $i$ studiowanie literatury wpływa na osobę i kształtuje jej świat wewnętrzny. Rzeczywistość literacka wyrasta $z$ doświadczenia - życiowego i językowego - odwołuje się do niego i na nim się opiera. Odbija i odwzorowuje w sobie językowy obraz świata, jednocześnie modyfikując zarówno sam język (na poziomie znaczeń i struktur), jak i wpisany weń obraz rzeczywistości - a dokonuje się to w różnego rodzaju językowych działaniach

13 Wśród atutów metody CLIL autorka wymienia „przełamywanie barier w przechodzeniu $z$ jednego języka na drugi”, „otwarcie na wielokulturowośc”, a także „uczenie się przez działanie, rozwiazywanie problemów, oddziaływanie na wszystkie zmysły" [Janus-Sitarz 2014, 252].

14 Justyna Hadaś, wychodzacc od tezy o ,aktywnej roli odbiorcy i twórczego charakteru czytania" [Goodman 1994; Rosenblatt 2004] oraz koncentrujac się na tworzeniu $=\mathrm{w}$ procesie zachodzącym między czytelnikiem a tekstem - znaczenia warunkowanego przez kontekst (wiedza i materiał), pisze o tworzeniu tekstu równoległego / odczytanego [zob. Hadaś 2020, 56]. 
przeobrażających (np. poprzez eksperyment językowy - neologizm, grę słów, synonimię, metaforę).

\section{Literatura w nauczaniu języka}

Kiedy czytamy teksty literackie, stosujemy różne strategie lekturowe. Zazwyczaj dążenie do zrozumienia tekstu kultury łączy się z koniecznościa podjęcia określonych działań, pokonania kolejnych etapów i niewątpliwie jest procesem złożonym. Ukazany poniżej zestaw rozwiązań dydaktycznych podpowiada, jak podażać za tekstem, jakie zadania należy wykonać, by $z$ tego tekstu wydobyć znaczenie, by tekst przemówił. Lektura utworu literackiego - w tym wypadku opowiadania Sławomira Mrożka zatytułowanego Rewolucja - przybiera formę sekwencji działań, dzięki którym poprzez kolejne czynności i pokonywanie barier - leksykalnych, gramatycznych, kulturowych i międzykulturowych, a także tych wynikających $z$ indywidualnych cech kreacji artystycznej - wnikamy głębiej, widzimy jaśniej i rozumiemy więcej. Podążanie tą droga, dokonywanie kolejnych odsłon (co przy czytaniu literatury jest niezbędne) zmienia się $\mathrm{w}$ przygodę intelektualna polegająca na poszukiwaniu znaczenia.

\section{Rozwiązania praktyczne, czyli rewolucja funkcjonalna ${ }^{15}$}

\section{POPRZEZ PYTANIA I ODPOWIEDZI}

Sławomir Mrożek (1930-2013), Borzęcin - Nicea (Francja); pisarz,
dramaturg (teatr absurdu), rysownik; debiut literacki Pótpancerze
praktyczne [1953]; inne zbiory opowiadań, np. Słon, Wesele
w Atomicach, Donosy; pierwsza sztuka teatralna Policja [1958];
inne dramaty: Indyk, Tango, Rzeźnia, Emigranci, Miłość na Krymie;
1963-96: Włochy - Francja - USA - Meksyk; 1996-2008 Kraków;
2008-13 Nicea; 2002 - udar mózgu i afazja (utrata możliwości
posługiwania się językiem w mowie i piśmie); w wyniku terapii
(Baltazar. Autobiografia) odzyskał sprawność mówienia i pisania.
Autor Dziennika.

\section{POPRZEZ SŁOWA}

\section{Proszę dopasować synonimy lub definicje:}

1. położenie $\quad \underline{\text { 1. }}$ pozycja, lokalizacja

2. ponowny - coś, co jest nowe

3. nowość - kolejny; nowy

4. wystarczać - niewygoda, brak komfortu

5. niedogodność — mieć tyle, ile potrzebuję

15 Zaprezentowane fragmenty materiałów dydaktycznych pochodzą $z$ podręcznika przygotowanego na potrzeby liceum polonijnego w USA [zob. Próchniak 2014, 169-184]. 
II. Proszę dopasować odpowiednie kolokacje do zdań:

a) nudzić się czym?

b) nuda dokucza komu?

c) coś znudziło się komu?

1. Ludzie szybko różnymi rzeczami.

2. Nuda nie ludziom, którzy lubią czytać.

3. Ta nieciekawa praca nam w jeden dzień.

III. Proszę dopasować opozycje (antonimy):

1. czułem ożywczy prąd nowości $1 . \quad \neq$ czułem nudę

2. coś jest źródłem nudy

3. ktoś godzi się na coś

4. podjąc decyzję $\neq$ nie móc się zdecydować $\neq$ ktoś nie zgadza się na coś $\neq$ coś ożywiło kogoś

IV. Proszę dopasować wyrazy do tekstu:

decyzja --- na stojąco --- spać --- stóp --- zasnać ---...

„(...) Postanowiłem spaćw szafie. Każdy, kto próbował spać w szafie ................ wie, że taka niewygoda w ogóle nie pozwala, nie mówiąc o omdlewaniu i bólach kręgosłupa. Tak, to była właściwa

3. POPRZEZ RYSOWANIE // POPRZEZ „OBRAZY ŚWIATA”

1.

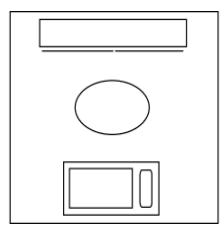

2.

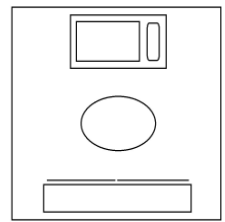

3.

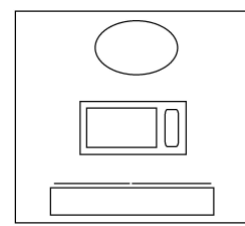

4.

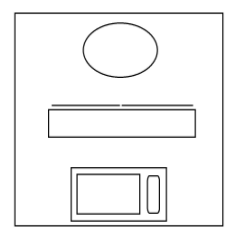

5.

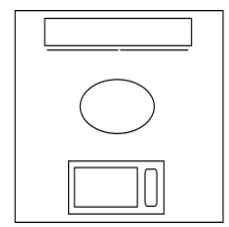

4. POPRZEZ TREŚĆ

\section{Proszę wskazać poprawne informacje:}

1. Bohaterem - i narratorem - opowiadania Rewolucja jest ... .
a) méżczyzna
b) kobieta
c) dziecko

2. Wśród opisanych mebli znajdują się szafa, stół i ... .
a) kanapa
b) sofa
c) łóżko

3. Bohater-narrator ... swoim pokojem, więc przestawił meble.
a) zainteresował się
b) znudził się
c) zmęczył się 
4. Po pewnym czasie bohater-narrator zorientował się, że nudny jest
a) stół, ponieważ stoi na środku
b) stół, ponieważ jest okrąły
c) cały dom

5. POPRZEZ STRUKTURY, CZYLI „gramatyczne łamigłówki”

VII. Proszę kontynuować zdania:

1. Interesuje mnie ...

2. Najbardziej cieszy mnie ...

3. Zawsze martwi mnie ...

4. Nigdy nie denerwuje mnie ...

5. (Nie) bardzo wzrusza(ja) mnie ...

6. Czasem nudzi mnie ...

\section{Proszę dopasować podane wyrazy do zdań:}

trzeba --- można --- wolno --- warto --- należy --- wypada

W szkole się uczyć.

nie rozmawiać przez telefon w czasie lekcji. rozmawiać $z$ kolegami w czasie przerwy. uczyć się języków. wykonywać różne zadania.

nie się kłócić.

\section{Proszę odpowiedzieć na pytania:}

1. Co trzeba robić, żeby dużo wiedzieć na jakiś temat?

Żeby dużo wiedzieć na jakiś temat, trzeba

2. Co trzeba robić, żeby wiedzieć, co się dzieje na świecie?

3. Co trzeba robić, żeby mieć sukcesy?

\section{Proszę zaproponować coś nowego:}

gdzie? / kiedy?

$$
\begin{aligned}
& \text { (nie) wolno } \\
& \text { (nie) można } \\
& \text { (nie) trzeba }
\end{aligned}
$$

\section{POPRZEZ DEFINIOWANIE - W DRODZE DO SYNTEZY}

\section{XII. a) Postawy życiowe - proszę dopasować wyrazy do ich definicji:} awangarda --- konformizm --- nonkonformizm --- rewolucja

konformizm (od łac. conformate - upodabniać) skłonność ludzi do myślenia, odczuwania i zachowywania się w taki sposób jak większość wokół nich niezgadzanie się $z$ ogólnie panujacymi poglądami, normami 
grupa ludzi, których działanie jest nowatorskie i niekonwencjonalne

proces dużych, gwałtownych zmian w jakiejś dziedzinie

\section{b) Która $z$ tych postaw życiowych jest typowa/niecodzienna/inte- resująca? Dlaczego?}

\section{Proszę odpowiedzieć na pytania:}

1. Jakim człowiekiem jest bohater-narrator w opowiadaniu Sławomira Mrożka pt. Rewolucja?

2. Jaki jest świat, w którym on żyje?

3. Co jest w jego pokoju, a czego tam brakuje?

4. Jakie sa relacje bohatera-narratora $z$ innymi ludźmi?

5. Czy pokój opisany w Rewolucji jest symbolem świata zewnętrznego czy wewnętrznego? Dlaczego?

6. Czy wieloznaczność wyrazu „pokój” jest ważna w opowiadaniu Rewolucja? Dlaczego?

7. Co inspiruje bohatera do działania - nuda czy ciekawość?

8. Jaki jest rezultat eksperymentów bohatera-narratora?

9. Jaka jest postawa bohatera - konformistyczna, nonkonformistyczna, awangardowa czy rewolucyjna?

10. Która $z$ tych postaw podoba ci się najbardziej? Dlaczego?

Zaproponowana lektura opowiadania Sławomira Mrożka ma charakter sekwencyjny. Faza poprzedzajaca czytanie dotyczy „zarysu postaci” autora, na który składa się rysunkowy autoportret, a także biograficzny szkic na wzór hasła ze słownika pisarzy. Ten pierwszy etap jest tak skondensowany i tak typowy, że w pewnych okolicznościach mógłby pozostać niezauważony i pominięty. Jeśli jednak poświęcimy mu trochę czasu i zamienimy automatyzm głośnego odczytania wstępnych informacji na próbę odtworzenia wybranych elementów biografii w formie dialogu (pytania lektora i odpowiedzi uczniów / studentów), okaże się, że można przywołać istotne fakty $z$ życia niezwykłego człowieka i artysty. Co na tę biografię się składa? Po pierwsze - przestrzenie, a to sugeruje wielokulturowość: od przyjścia na świat w podkrakowskim Borzęcinie, poprzez kolejne osiedlenia w różnych krajach i na różnych kontynentach, po powrót do Polski po 33 latach emigracji i schyłek życia w Nicei. Po drugie - sztuka, a to znaczy groteskowy, pełen absurdu świat w słowach i kreskach: opowiadania, dramaty, autobiografia i cykle rysunków. Po trzecie - udar mózgu i afazja, a więc język, czyli panowanie nad językiem i utrata tego panowania oraz powiazana $z$ tym świadomość jego „organicznej” utraty, a następnie odzyskiwanie języka - najpierw polskiego, później również angielskiego i francuskiego - w pisaniu, w procesie tworzenia literatury, bo w czasie terapii powstała książka: Baltazar. Autobiografia. Bez wątpienia osiemdziesięciotrzyletnie życie Mrożka ma więcej wymia- 
rów, a jednak te trzy koncentrują nasza uwagę na sprawach ważnych i w pewien sposób uniwersalnych. I jeśli nawet w pamięci czytelników Rewolucji pozostanie jedynie wyobrażenie autora satyrycznych rysunków i groteskowego świata opisywanego w opowiadaniach, kreowanego w dramatach, to jest to ważny punkt wyjścia, sposób budzenia ciekawości, impuls do dalszych poszukiwań.

Następny etap to przejście od autora do twórczości. Sformułowanie obiegowej definicji rewolucji nie nastręczy specjalnych trudności. Odwołując się do tytułu, uczniowie/studenci mogą spróbować przewidywać treść utworu. Jednak już pierwsza - głośna - lektura uzmysłowi, że opisana $\mathrm{w}$ tekście rewolucja nie dotyczy podstawowego znaczenia tego słowa. Tekst powinien zostać głośno przeczytany; można również wykorzystać nagranie. Opowiadanie jest krótkie, ale też bardzo skondensowane, dlatego zapoznanie się $z$ nim wymaga koncentracji. Poza tym kolejne zadania zmuszą uczniów/studentów do ponawiania lektury całego opowiadania lub jego fragmentów. Taka technika dydaktyczna jest jak najbardziej uzasadniona - także wyrobiony czytelnik powraca wielokrotnie do utworu, który chciałby zrozumieć i zinterpretować.

Natomiast uważniejsze przyjrzenie się kolejnym zadaniom pokaże, że istotne etapy $\mathrm{w}$ drodze do zrozumienia polegaja na pokonywaniu barier leksykalnych i gramatycznych, a rozwiązywanie ćwiczeń wiąże się $z$ aktywizowaniem sprawności (słuchanie, mówienie, czytanie i pisanie) i działań językowych (produkcja, mediacja, interakcja). Konieczne jest również doprecyzowanie kontekstów i szczegółów kulturowych. Dzięki temu uczestnicy zajęć rozwijaja nie tylko wiedzę, ale także, wnikając w głębsze warstwy znaczeniowe, koncentruja się na przekazie „ukrytym” pod powierzchnia słów. Ostatecznie to, co początkowo wydaje się zwykłym cyklem zadań do wykonania, układa się w proces analityczno-interpretacyjny, prowadzi do wniosków i syntetycznego ujęcia przekazu, a pytania zawarte w ostatnim ćwiczeniu skłaniaja do formułowania własnych refleksji, opinii, przekonan - tych związanych $z$ tekstem bezposrednio i tych tekstem inspirowanych.

Ważne jest również to, że czytanie Rewolucji na lekcji języka polskiego jako obcego prowadzi do formułowania dalszych wniosków. Uczniowie zwracaja uwagę na specyficzny rytm tekstu, na operowanie krótkimi zdaniami, które często przybierają formę elipsy, na tautologie i aliteracje, które wpływaja na brzmienie i na znaczenie - na przykład na szczególną funkcję czasu, który wraz z nudą napędza opisaną rzeczywistość. Jedna $z$ ciekawszych obserwacji było spostrzeżenie, że nie tylko świat Rewolucji jest ubogi, uproszczony (znaczaca i przytłaczajacca jest nieobecność innych ludzi, a w przywołanej przestrzeni - brak okien i drzwi), ale że również sam bohater-narrator jest człowiekiem niekompletnym, niepełnym. Tekst jednak podpowiada, że ma on twarz (więc jest kimś, kto „zachował twarz”, nie wyrzekł się swoich przekonań), kręgosłup (nie jest zatem osoba „bez kręgosłupa”, pozbawiona zasad moralnych), stopy 
(które pozwalają mu „stanąc na własnych nogach”) i prawdopodobnie ręce (działa „na własną rękę”, „ma pełne ręce roboty”, a może po prostu „bierze sprawy w swoje ręce”, by ostatecznie „machnąć ręką" na podejmowane próby). Uderzające wydaje się również odniesienie opisanego świata i bohatera do naszej rzeczywistości i kondycji nas samych żyjących tu i teraz - ludzi w izolacji wymuszonej lub wynikajaccej $z$ wyboru określonego stylu życia.

\section{KULTURA, CZYLI POWIETRZE, KTÓRYM ODDYCHAMY}

Cele kognitywno-afektywne - wpisane w zaprezentowana powyżej lekturę Rewolucji - łącza procesy intelektualne ze sfera emocji i postaw, sprzyjaja przyswajaniu nowych treści i przynosza efekty dydaktyczne. Zajęcia opieraja się na dialogu, są spotkaniem $-z$ tekstem kultury, $z$ możliwymi wariantami życia, $z$ wartościami lub ich brakiem. Sa też przestrzenia wymiany myśli, wyrażania opinii, emocjonalnych reakcji językowych, a przez to staja się forma aktualizowania się kultury jako dynamicznego procesu tworzenia relacji [Kramsch 1993; Torenc 2007, 105].

Zamykając się w kręgu metody komunikacyjnej, akcentujemy powierzchnię języka i jego funkcjonalność jako narzędzia. Ważne jednak jest również sięgnięcie w głąb, by uświadomić sobie nie tylko złożoność gramatyczną i semantyczną przyswajanego języka, ale również jego wartość symboliczna i duchowa, a to nie jest możliwe bez poznawania warstwy kulturowej [por. Żylińska 200].

Celem nadrzędnym we współczesnej glottodydaktyce jest komunikacja. Nauczanie języka za pomoca „prostych komunikatów” zaopatruje uczącego się w proste narzędzia. Powinnišmy jednak mieć na względzie również ten niepokój - nauczajaccych i uczących się - gdy językowe panowanie nad jedynie codziennymi czy też zawodowymi potrzebami odsłania swój niepełny, ograniczony - i ograniczający - charakter.

\section{Bibliografia}

M. Bennett, 1993, Towards Etnoreltivism: A Development Model of Intercultural Sensitivity [w:] R. Paige (red.), Education to the Intercultural Experience, Yarmouth, s. 21-71.

J. Bolten, 2006, Interkulturowa kompetencja, thum. i wprowadzenie B. Andrzejewski, Poznań.

J. Bolten, 2010, Kompetencja interkulturowa w e-learningu, thum. K. Gaca [w:] M. Mackiewicz (red.), Kompetencja interkulturowa $w$ teorii i praktyce edukacyjnej, Poznań, s. 265-280.

M. Byram, 1997, Teaching and Assessing Intercultural Communicative Competence, Clevedon. 
G.M. Chen, W.J. Starosta, 1996, Intercultural communication competence. A synthesis [w:] B. Burleson (red.), Communication Yearbook 19, Thousand Oaks, s. 353-383.

R. Cudak, W. Hajduk-Gawron, A. Madeja (red.), 2018, Na wyrywki. 100 cytatów $z$ polskiej poezji i dramatu, które powinien znać także cudzoziemiec, Katowice.

T. Czerkies, 2012a, Kultura jako przestrzeń ścierajacych się dyskursów i negocjowania znaczeń. O nauczaniu języka polskiego jako obcego opartym na etnografii mówienia oraz filozofii konfliktu, „Acta Universitatis Lodziensis. Kształcenie Polonistyczne Cudzoziemców” t. 19, s. 23-34.

T. Czerkies, 2021b, Tekst literacki $w$ nauczaniu języka polskiego jako obcego (z elementami pedagogiki dyskursywnej), Kraków.

T. Czerkies, 2016, Bliżej tekstów, Seul.

T. Czerkies, 2019, Literackie lustro kultury. Literatura polska w ćwiczeniach dla obcokrajowców - poziom B.1.2-C1, Kraków.

ESOKJ, 2003: Europejski system opisu kształcenia językowego: uczenie się - nauczanie-ocenianie, tłum. W. Martyniuk, Warszawa.

M.C. Gertsen, 1990, Intercultural competence and expatriates, „The International Journal of Human Resource Management" vol. 1, s. 341-362.

P. Gębal, 2006, Realia i kultura w nauczaniu języka polskiego jako obcego [w:] E. Lipińska, A. Seretny (red.), Z zagadnień dydaktyki języka polskiego jako obcego, Kraków, s. 205-242.

J. Hadaś, 2020, Świadomość kultury w krytycznym czytaniu w języku obcym na przykładzie rodzimych użytkowników języka polskiego, Poznań.

A. Handzel, 2014, Content and Language Integrated Learning jako metoda ułatwiajaca przełamywanie bariery komunikacyjnej w nauczaniu języków obcych, „Acta Universitatis Lodziensis. Kształcenie Polonistyczne Cudzoziemców" t. 21, s. 145-152.

A. Janus-Sitarz, 2014, Jak poszerzać kompetencje polonisty? Nauczyciel CLIL, czyli zintegrowane nauczanie języka i przedmiotu [w:] A. Janus-Sitarz (red.), Polonistyka szkolna zanurzona w jezzyku, Kraków, s. 247-260.

S. Jaskuła, L. Korporowicz, 2017, Współczesne paradygmaty dialogu międzykulturowego, „Edukacja Humanistyczna” nr 2 (37), s. 33-43.

P. Kaikkonen, 1997, Fremdverstehen durch den schulischen Fremdsprachenunterricht. Einige Aspekte zum interkulturellem Lernen, Info DaF nr 1, s. 78-86.

M. Korczyński, 2017, Kompetencje międzykulturowe polskich emigrantów zarobkowych w Anglii, „Lubelski Rocznik Pedagogiczny” t. XXXVI, z. 3, s. 151-175.

J. Kowalewski, 2013, Od A do C-problemy z metoda komunikacyjna $w$ nauczaniu języka polskiego jako obcego poza Polska. Program kulturowy jako alternatywa dla podejścia zadaniowego, „Acta Universitatis Lodziensis. Kształcenie Polonistyczne Cudzoziemców” t. 20, s. 261-270.

C. Kramsch, 1993, Context and Culture in the Language Teaching, Oxford.

A. Kwiatkowska, M. Valkova Maciejewska (red.), 2018, Literatura i glottodydaktyka $w$ praktyce. Tekst literacki $w$ nauczaniu języka polskiego jako obcego, Poznań.

A. Majkiewicz, 2016, Czy można nauczyć się kompetencji interkulturowej?, „Prace Naukowe Akademii im. Jana Długosza w Częstochowie” t. XXV, s. 113-125.

K. Mihułka, 2014, Dylematy współczesnej glottodydaktyki: język - kultura, interlingwalizm - interkulturowość, „Języki Obce w Szkole” nr 3, s. 78-87.

D. Mostwin, 1995, Trzecia wartość. Wykorzenienie i tożsamość, Lublin. 
S. Mrożek, 1986, Rewolucja [w:] tegoż, Opowiadania, Lublin, s. 27-28.

K. Myczko, 2005, Kompetencja interkulturowa jako cel kształcenia językowego [w:] M. Mackiewicz (red.), Dydaktyka języków obcych a kompetencja kulturowa i komunikacja interkulturowa, Poznań, s. 27-35.

J. Nikitorowicz i in., 2013, Kompetencje do komunikacji międzykulturowej $w$ aspekcie wielokulturowości regionu i procesów migracyjnych, Warszawa.

R. Nycz, 2017, Kultura jako czasownik. Sondowanie nowej humanistyki, Warszawa.

T. Paleczny, 2017, Wymiary analizy relacji międzykulturowych, „Relacje Międzykulturowe. Intercultural Relations" nr 1: Relacje międzykulturowe jako przedmiot badań, red. M. Banaś, F. Czech, Kraków, s. 29-55.

W. Pfeiffer, 2001, Nauka języków obcych. Od praktyki do praktyki, Poznań.

W. Próchniak, 2012, Klucz do wierszy. Poezja w nauczaniu języka polskiego jako obcego, Lublin.

W. Próchniak, 2014, Literatura polska 20. i 21. wieku. Teksty i ćwiczenia, Chicago.

W. Próchniak, 2018, Tekst literacki, czyli zjawisko ekstremalne (w glottodydaktyce) [w:] A. Kwiatkowska, M. Valkova Maciejewska (red.), Literatura i glottodydaktyka $w$ praktyce. Tekst literacki $w$ nauczaniu języka polskiego jako obcego, Poznań, s. 13-29.

W. Próchniak, 2020, Poezja kultury - kultura (w) poezji [w:] J. Zych (red.), Literackie obrazy kultury. Perspektywa glottodydaktyczna, Warszawa, s. 44-64.

A. Świdzińska, W. Maliszewski, 2019, Afektywny wymiar kompetencji do komunikacji interkulturowej studentów pogranicza polsko-białoruskiego, „Annales Universitatis Mariae Curie-Skłodowska" t. XXXII, 2, s. 161-173.

A. Thomas, 2003, Analyse Handlungswirksamkeit von Kulturstandards [w:] A. Thomas (red.), Psychologie Interkulturellen Handelns, Gottingen, s. $107-135$.

M. Torenc, 2007, Nauczanie międzykulturowe - implikacje glottodydaktyczne, Wrocław.

A. Wierzbicka, 1990, Podwójne życie człowieka dwujęzycznego [w:] W. Miodunka (red.), Jezzyk polski $w$ świecie. Zbiór studiów, Kraków, s. 71-104.

W. Wilczyńska, 2012, Czy pojęcie dyskursu jest przydatne $w$ glottodydaktyce?, „Neofilolog” 38/1: Dyskurs edukacyjny w klasie językowej, red. M. Pawlak, Poznań-Kalisz, s. 7-25.

W. Wilczyńska, 2013, Dyskurs - brakujace ogniwo nierozerwalności kultury i języka, czyli o integracji $w$ kształceniu neofilologów, „Lingwistyka Stosowana” 8, s. 133-152.

G. Zarzeczny, T. Piekot, 2010, Inny punkt widzenia - treści kulturowe $w$ podręcznikach oczami cudzoziemców [w:] P. Garncarek, P. Kajak, A. Zieniewicz (red.), Kanon kultury $w$ nauczaniu języka polskiego jako obcego, Warszawa, s. $199-206$.

G. Zarzycka, 2000, Dialog międzykulturowy. Teoria oraz opis komunikowania sie cudzoziemców przyswajajacych język polski, „Acta Universitatis Lodziensis. Kształcenie Polonistyczne Cudzoziemców” t. 11.

G. Zarzycka, 2008, Jak powstaja hasła do Leksykonu kultury polskiej dla cudzoziemców?, „Acta Universitattis Lodziensis. Kształcenie Polonistyczne Cudzoziemców" nr 16, s. 183-189. 
J. Zych (red.), 2020, Literackie obrazy kultury. Perspektywa glottodydaktyczna, Warszawa.

U. Żydek-Bednarczuk, 2015, Spotkanie kultur. Komunikacja i edukacja międzykulturowa $w$ glottodydaktyce, Katowice.

M. Żylińska, 2003, Podejście interkulturowe, czyli o konieczności zmian w nauczaniu języków obcych, „Języki Obce w Szkole” nr 6, s. 49-62.

\section{Rewolucja funkcjonalna.}

\section{O literackich $i$ kulturowych aspektach nauczania jezyka polskiego jako obcego}

Streszczenie

Artykuł zawiera krótki przegląd metod stosowanych obecnie w glottodydaktyce polonistycznej oraz omówienie niektórych zjawisk związanych $z$ interkulturowością. Istotnym elementem artykułu jest propozycja nauczania językowo-kulturowego na podstawie opowiadania Sławomira Mrożka pod tytułem Rewolucja.

Słowa klucze: glottodydaktyka polonistyczna - metoda komunikacyjna, zadaniowa i interkulturowa - kultura - literatura.

\section{Functional Revolution. \\ On the literary and cultural aspects of teaching Polish as a foreign language}

Summary

The paper contains a short overview of the currently used methods of teaching Polish as a foreign language and a discussion of some phenomena related to interculturalism. The essential element of the paper is the linguistic and cultural teaching proposal based on a short story by Sławomir Mrożek titled Rewolucja (Revolution).

Keywords: Polish language teaching - communication - task and intercultural methods - culture - literature.

Adj. Monika Czarnecka 